\title{
The Model Organization of Early Childhood Education in Organizational Capacity Development
}

\author{
Iskhak; Sundarso, Hardi Warsono; Ida Hayu Dwimawanti \\ Public Administration Doctoral Program, Faculty of Social and Political Science \\ Diponegoro University \\ Semarang, Indonesia \\ (Office Email: prodidap@gmail.com)
}

\begin{abstract}
Model theory system is the organizational capacities of the concept correlated with more comprehensive and appropriate when applied to the early childhood education (OLD). Model organizational capacity development includes technical capacity Organization (educators and educational personnel and infrastructure, financing and curriculum), management capacity (leadership leader/head of Agency/ Principal), institutional Organization Capacity (The Policy in an environment of early childhood education). The educator is the key for teaching and learning, educational personnel preparation key to success holder and the post instruction. The principal is prerequisite skill (skill in leadership, human, group process, personnel administration, and skill in evaluation). Medium duty/role of the school head is known as EMASLIMo (Educator, Administrator, Supervisor, Leader, Innovator and Motivator).
\end{abstract}

Keywords-Educator; Education; Children

\section{INTRODUCTION}

On the model theory of the system if in correlates with the concept of organizational capacity is more comprehensive in describing models of early childhood education. Model-the model can be divided into three types of organizational capacity: Transcending dualisms, integrating the activity approach with naturalistic approach within a coherent framework, linking the study — a study of micro (micro studies) about/interaction actions and knowledge with the theories macro (macro theories) about the social and institutional structures.

Based on the model of systems theory, system activity and organizing model early childhood education in the development of the capacity of the Organization, then the capacity parameters of becoming standard in this research are: a. the technical capacity of the Organization (educators and educational personnel and infrastructure, financing and curriculum), b. managerial Capacity (leadership leader/head of Agency/Principal) and c. the institutional Capacity of the Organization (The Policy in an environment of early childhood education). Those factors as a major factor in early childhood education in the mengukurdan to develop the capacity of the Organization, with an explanation as follows:

\section{A. The technical capacity of the Organization}

Technical capacity of the will be examined in this section include: educators and educational personnel and infrastructure, financing and curriculum.

\section{B. Educators and Educational Personnel}

According to law No. 20 of 2003 on the national education system, article 39 paragraph 2, educator is a professional in charge of planning and implementing the process of learning, assessing learning outcomes, conduct supervision and training, as well as conducting research and devotion to society, especially for educators at the College.

In particular the duties and functions of educators (teachers and professors) are based on the regulation of the Minister of national education no. 14 of 2007, i.e., as agents of learning to improve the quality of national education, developer of the science, technology, and art, as well as servants to the community. Standard of produce educators and Educators is the criteria regarding the education of duties and the feasibility as well as mental, as well as in the Office of education according to the Government Regulation Number 32 year 2013.

Educators on Education generally includes: teachers, professors, counselors, teachers learn, widyaiswara, tutors, constructive, facilitators, teachers, early childhood education teacher supervisor and technical resource educative.

Educational personnel includes: Unit Manager education, overseer, supervisors, researchers, developers, power laboratory, power, library technicians learning resources, personnel administration, educational psychologist, social workers, therapists, energy cleanliness and security.

\section{Workforce Management}

Educators and educational management are activities that must be done starting from educators and educational entry into organizations of education until it finally stopped. It can be said also was a series of workforce management processes for regulating the procedures of planning, procurement, construction and development, placement and assignments, promotions and compensation, termination, mutation, as well as the assessment of produce educators. 


\section{Infrastructure and Facilities}

Educational facilities and infrastructure is the thing that can't be ignored in creating learning activities or activities of quality education (education and culture, 200:41). Education is a means of equipment or furniture schools/institutions needed in carrying out the activities of the institutions, especially educational/process, among other things: tables, chairs, whiteboards, lap top and its apparatus, film and other

The education infrastructure is a means of education supplies before making such as land, buildings, and other pages There are three (3) management of the physical environment of the school, namely: Site or ground school, the building and the school grounds. The size of the land area for the OLD is the page on the national standards of education.

Soetjipto, (2009) reveals that the educational infrastructure and facilities are all moving or not moving objects that are required to support the learning process of teaching directly or indirectly. Infrastructure is a tool or medium of moving or not and useful help teaching and learning or educational process.

\section{E. Financing}

Strategies that allow effective provide financing depends greatly on the approach to the specificities and characteristics of the region, through the Central Government, as well as nonprofit organizations (Behmen et al, 2006). Early childhood education more financed private parties, individuals, organizations or communities, because many private institutions instead of OLD institutions.

Meijer et al. (1995) in the Fletcher Campbell et al. (2003) stated that there are two major aspects in financing, that means (the way or means by which is financed) such as time, money, and training facilities, and the destination for the means (the target of a way or means used for the achievement, including: parents, students, school, community, local institution and so on).

\section{F. Curriculum}

Curriculum development is carried out with reference to the national standards of education in order to realize the goal of national education (Law No. 20 in 2003, article 36 paragraph 1). To improve the quality of education in Indonesia has implemented six times change curriculum, namely curriculum 1968, 1975, 1984, 2004 curriculum and now apply i.e. the curriculum level unit of education (KTSP), issued by the Government through the Candy Department number 22 standard of the content, Number 23 on standard Candy graduates, and Number 24 on the implementation of Candy, 2006. Curriculum unit level education (KTSP) is the revision and development of a competency-based curriculum, curriculum or 2004.

\section{G. Managerial Capacity; The leadership of the head of school/institution}

A leader is one who has the ability to affect the behavior of others in his work using his power (Stoner and Brian Mitchell, 2000, 48-49). He also expressed competence is the ability to direct and influence the subordinates in connection with tasks that need to be implemented. Gary Yull, (1994), the leadership contingency that can be applied to various situations effectively. Currier Davis (1991, 2-3) mentions that the leadership is one of the factors that must be present in the Organization, with the definition: "It has been pointed out that the organization consist of a group of individual cooperating under the ENE of executive leadership toward the accomplishment of certain common objective" (Has stated that an organization composed of a group of people who work under the direction of the Executive leadership for the achievement of the general objective is for sure). The leadership as a concept of management has a strategic position and is absolutely necessary in the management of the school so that the school's purpose can be achieved (Moe, 2000).

There are five skills that should be possessed by the Principals in leading institutes, namely: skills in leadership (skill in leadership), human relations Skills (skill in human), (skill in personnel administration), evaluating the Skills (skill in Group process skills (skill in group process), select the Skills of personnel evaluation).

The MoE (2000, 3-7) formulate implementation tasks/roles of the head of school as EMASLIMo (Educator, Administrator, Supervisor, Leader, Innovator and Motivator). From the explanation above, the role of the headmaster's leadership became the primary focus in the development of the organization.

\section{H. Institutional Capacity of the Organization}

On the capacity of institutions of this organization to discuss two important points in the development of early childhood educational institution, namely: network professionals and policy on early childhood education.

\section{REFERENCES}

[1] Behmen ( 2006 ), Exploring Strategies to Advance Public Sector Funding in Gereriartr, Journal of Social Work Edocation.

[2] Buchori, Achmad R 2010. Pelayanan Publik Dalam Bingkai Birokrasi. Jurnal Administrasi Negara.

[3] Dwiyanto, Agus. 2008. Mewujudkan Good Governance Melalui Pelayanan Publik. Yogyakarta: Gajah Mada University Press.

[4] Gary Yukl (1998) Leadership in Organizations 3e. Jakarta. Prenhallindo

[5] Patmonidewo, Soemiarti ( 2003 ) Pendidikan Anak Prasekolah. Jakarta: Rineka Cipta

[6] Ratminto \& Atik Septi Winarsih, (2005), "Manajemen pelayanan : Pengembangan Model Konseptual, penerapan Citizen's Charter dan Estandar Pelayanan Minimal”, Yogyakarta: Pustaka Pelajar 